\title{
Patient-facing mobile apps: Are ObGyns uniquely positioned to integrate them into practice?
}

\section{Part of the assessment and plan also could include prescribing apps}

\author{
Bryana Banashefski, BS, and Katherine T. Chen, MD, MPH
}

ncorporating mobile apps into patient care programs can add immense value. Mobile apps enable data collection when a patient is beyond the walls of a doctor's office and equip clinicians with new and relevant patient data. Patient engagement apps also provide a mechanism to "nudge" patients to encourage adherence to their care programs. These additional data and increased patient adherence can enable more personalized care, ${ }^{1}$ and ultimately can lead to improved outcomes. For example, a meta-analysis of 1,657 patients with diabetes showed a $5 \%$ reduction in hemoglobin $A_{1 c}\left(H_{b A_{1 c}}\right)$ values for those who used a

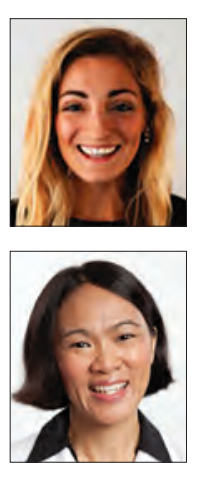

Ms. Banashefski is a first-year medical student at the Icahn School of Medicine at Mount Sinai, New York, New York.

Dr. Chen is Vice-Chair of Ob-Gyn Education for the Mount Sinai Health System and Professor of Obstetrics, Gynecology, and Reproductive Science and Medical Education, Icahn School of Medicine at Mount Sinai. She is an OBG MANAGEMENT Contributing Editor.

Ms. Banashefski reports no conflicts of interest relevant to this article. Dr. Chen reports being an advisory board member and receiving royalties from UpToDate, Inc.

doi: 10.12788/obgm.0102 diabetes-related app. ${ }^{2}$ The literature also shows positive results for heart failure, weight management, smoking reduction, and lifestyle improvement. ${ }^{3-5}$ Given their value, why aren't patient engagement apps more routinely integrated into patient care programs?

From a software development perspective, mobile apps are fairly easy to create. However, from a user retention standpoint, creating an app with a large, sustainable userbase is challenging. ${ }^{5}$ User retention is measured in monthly active users. We are familiar with unused apps collecting digital dust on our smartphone home screens. A 2019 study showed that $25 \%$ of people typically use an application only once, ${ }^{6}$ and health care apps are not an exception. There are hundreds of thousands of mobile health apps on the market, but only $7 \%$ of these applications have more than 50,000 monthly active users. Further, $62 \%$ of digital health apps have less than 1,000 monthly active users. $^{7}$

Using a new app daily or several times weekly requires new habit formation. Anyone who has tried to incorporate a new routine into their daily life knows how difficult habit formation can be. However, ObGyn patients may be particularly well suited to incorporate ObGyn-related apps into their care, given how many women already use mobile applications to track their menstrual cycles. A recent survey found that across all age
IN THIS ARTICLE

Top contraception education apps

page 56

Top medication adherence apps

page 57 
TABLE 1 TOp 3 recommended contraception education mobile apps

\begin{tabular}{|c|c|c|c|c|c|}
\hline App & Comprehensiveness & Price & Platform & $\begin{array}{l}\text { Literature } \\
\text { used }\end{array}$ & $\begin{array}{c}\text { Important special } \\
\text { features }\end{array}$ \\
\hline $\begin{array}{l}\text { Conifer } \\
\text { iTunes: https://apps.apple.com/us/app } \\
\text { /conifer-sex-health/id765571963 }\end{array}$ & $\begin{array}{l}\text { - Modern reversible } \\
\text { methods } \\
\text { - Effectiveness of } \\
\text { each method } \\
\text { - Side effects }\end{array}$ & Free & iTunes & None listed & $\begin{array}{l}\text { - Clinic locator (UK } \\
\text { only) } \\
\text { - STI prevention }\end{array}$ \\
\hline $\begin{array}{l}\text { KIS-SK (Keep it Safe SK) } \\
\text { iTunes: https://apps.apple.com/us/app } \\
\text { /kis-sk-keep-it-safe-sk/id870973586 } \\
\text { Google Play: https://play.google.com } \\
\text { /store/apps/details?id=com.college } \\
\text { mobile.spi.app\&hl=en_US\&gl=US }\end{array}$ & $\begin{array}{l}\text { Modern reversible } \\
\text { methods } \\
\text { - Effectiveness of } \\
\text { each method } \\
\text { - Side effects }\end{array}$ & Free & $\begin{array}{l}\text { iTunes and } \\
\text { Google Play }\end{array}$ & None listed & $\begin{array}{l}\text { - Clinic locator } \\
\text { (Canada only) } \\
\text { - STI prevention }\end{array}$ \\
\hline $\begin{array}{l}\text { NeedTayKnow } \\
\text { iTunes: https://apps.apple.com/us/app } \\
\text { /needtayknow/id567715876 } \\
\text { Google Play: https://play.google.com } \\
\text { /store/apps/details?id=com.faffdigital } \\
\text {.NeedTayKnow\&hl=en_US\&gl=US }\end{array}$ & $\begin{array}{l}\text { Modern reversible } \\
\text { methods } \\
\text { - Effectiveness of } \\
\text { each method }\end{array}$ & Free & $\begin{array}{l}\text { iTunes and } \\
\text { Google Play }\end{array}$ & None listed & $\begin{array}{l}\text { - Clinic locator (NY } \\
\text { only) } \\
\text { - STI prevention }\end{array}$ \\
\hline
\end{tabular}

groups, $47 \%$ of women use a mobile phone app to track their menstrual cycle, ${ }^{8}$ compared with $8 \%$ of US adults who regularly use an app to measure general health metrics. ${ }^{7}$ This removes one of the largest obstacles of market penetration since the habit of using an app for ObGyn purposes has already been established. As such, it presents an exciting opportunity to capitalize on the userbase already leveraging mobile apps to track their cycles and expand the patient engagement footprint into additional features that can broaden care to create a seamless, holistic patient application for ObGyn patient care.

One can envision a future in which a patient is "prescribed" an ObGyn app during their ObGyn appointment. Within the app, the patient can track their health data, engage with health providers, and gain access to educational materials. The clinician would be able to access data captured in the patient app at an aggregate level to analyze trends over time.

Current, patient-facing ObGyn mobile apps available for download on smartphones are for targeted aspects of ObGyn health. For example, there are separate apps for menstrual cycle tracking, contraception education, and medication adherence tracking. In the future, it would be ideal for clinicians and patients to have access to a single, holistic ObGyn mobile app that supports the end-to-end ObGyn patient journey, one in which clinicians could turn modules on or off given specific patient concerns. The technology for this type of holistic patient engagement platform exists, but unfortunately it is not as simple as downloading 
TABLE 2 Top 3 recommended patient medication adherence mobile apps

\begin{tabular}{|c|c|c|c|c|c|}
\hline App & Comprehensiveness & Price & Platform & $\begin{array}{l}\text { Literature } \\
\text { used }\end{array}$ & $\begin{array}{c}\text { Important } \\
\text { special features }\end{array}$ \\
\hline $\begin{array}{l}\text { Dosecast } \\
\text { iTunes: https://apps.apple.com/us } \\
\text { /app/dosecast-my-pill-reminder-app } \\
\text { /id365191644 } \\
\text { Google Play: https://play.google.com } \\
\text { /store/apps/details?id=com.montuno } \\
\text { software.dosecast\&hl=en_US\&gl=US }\end{array}$ & $\begin{array}{l}\text { - Medication tracking } \\
\text { history } \\
\text { - Refill reminders } \\
\text { - Flexible scheduling } \\
\text { - Data export and } \\
\text { sharing }\end{array}$ & $\begin{array}{l}\text { Free for } \\
\text { basic } \\
\text { version; } \\
\text { in app } \\
\text { purchases } \\
\text { offered }\end{array}$ & $\begin{array}{l}\text { iTunes and } \\
\text { Google } \\
\text { Play }\end{array}$ & None listed & $\begin{array}{l}\text { - Reminders with } \\
\text { no connectivity }\end{array}$ \\
\hline $\begin{array}{l}\text { Medisafe } \\
\text { iTunes: https://apps.apple.com/us/app } \\
\text { /medisafe-medication-management } \\
\text { /id573916946 } \\
\text { Google Play: https://play.google.com } \\
\text { /store/apps/details?id=com.medisafe } \\
\text {.android.client\&hl=en_US\&gl=US }\end{array}$ & $\begin{array}{l}\text { - Medication tracking } \\
\text { history } \\
\text { - Flexible scheduling } \\
\text { - Data export and } \\
\text { sharing } \\
\text { - Refill reminders } \\
\text { - Notification of other } \\
\text { people } \\
\text { - Adherence statistics } \\
\text { and charts }\end{array}$ & $\begin{array}{l}\text { Full } \\
\text { version } \\
\text { available } \\
\text { for free }\end{array}$ & $\begin{array}{l}\text { iTunes and } \\
\text { Google } \\
\text { Play }\end{array}$ & None listed & $\begin{array}{l}\text { - Medication } \\
\text { database } \\
\text { - Reminders with } \\
\text { no connectivity } \\
\text { - Time zone } \\
\text { support } \\
\text { - Multilingual }\end{array}$ \\
\hline $\begin{array}{l}\text { MyMeds } \\
\text { iTunes: https://apps.apple.com/us/app } \\
\text { /mymeds-med-tracking-made-easy } \\
\text { /id541882256 } \\
\text { Google Play: https://play.google } \\
\text {.com/store/apps/details?id=com } \\
\text {.mymeds\&hl=en_US\&gl=US }\end{array}$ & $\begin{array}{l}\text { - Medication tracking } \\
\text { history } \\
\text { - Refill reminders } \\
\text { - Adherence statistics } \\
\text { and charts }\end{array}$ & $\begin{array}{l}\text { Free for } \\
\text { basic } \\
\text { version; } \\
\text { in app } \\
\text { purchases } \\
\text { offered }\end{array}$ & $\begin{array}{l}\text { iTunes and } \\
\text { Google } \\
\text { Play }\end{array}$ & None listed & $\begin{array}{l}\text { Medication } \\
\text { database } \\
\text { - Reminders with } \\
\text { no connectivity }\end{array}$ \\
\hline
\end{tabular}

a mobile app. Standing up an end-to-end patient engagement platform requires enterprise-wide buy-in, tailoring user workflows, and building out integrations (eg, integrating provider dashboards into the existing electronic health record system). Full-scale solutions are powerful, but they can be expensive and time consuming to stand up. Until there is a more streamlined, outside-the-box ObGyn-tailored solution, there are patientfacing mobile apps available to support your patients for specific concerns.

The top 3 recommended menstrual cycle tracking apps from Moglia and colleagues ${ }^{9}$ are listed in Dr. Chen's article, "Top free menstrual cycle tracking apps for your patients." ${ }^{10}$ The top 3 recommended contraception education mobile apps from Lunde and colleagues ${ }^{11}$ are listed in TABLE 1 and are detailed with a shortened version of the APPLICATIONS scoring system, APPLI (app comprehensiveness, price, platform, literature use, important special features)..$^{12}$ The top 3 recommended patient medication adherence mobile apps from the study by Santo and colleagues ${ }^{13}$ are listed in TABLE 2. The apps in the Stoyanov et al ${ }^{14}$ study were evaluated using the 23-item Mobile App Rating System scale. 


\section{References}

1. van Dijk MR, Koster MPH, et al. Healthy preconception nutrition and lifestyle using personalized mobile health coaching is associated with enhanced pregnancy chance. Reprod BioMed Online. 2017;35:453-460. doi:10.1016/j. rbmo.2017.06.014.

2. Liang $X$, Wang Q, Yang $X$, et al. Effect of mobile phone intervention for diabetes on glycaemic control: a metaanalysis. Diabet Med. 2011;28:455-463. doi:10.1111/j.14645491.2010.03180.x.

3. Laing BY, Mangione CM, Tseng C-H, et al. Effectiveness of a smartphone application for weight loss compared with usual care in overweight primary care patients. Ann Intern Med. 2014;161(10 suppl):S5-S12. doi:10.7326/m13-3005.

4. Dennison L, Morrison L, Conway G, et al. Opportunities and challenges for smartphone applications in supporting health behavior change: qualitative study. J Med Internet Res. 2013;15:E86. doi:10.2196/jmir.2583.

5. Schoeppe S, Alley S, Van Lippevelde W, et al. Efficacy of interventions that use apps to improve diet, physical activity and sedentary behaviour: a systematic review. Int J Behav Nutr Phys Act. 2016;13:127. doi:10.1186/s12966016-0454-y.

6. $25 \%$ of users abandon apps after one use. Upland Software website. Accessed May 6, 2021. https://uplandsoftware.com /localytics/resources/blog/25-of-users-abandon-apps-afterone-use/.

7. mHealth economics $2017 / 2018$ - connectivity in digital health. Published March 5, 2019. Accessed May 6, 2021. https:// research2guidance.com/product/connectivity-in-digitalhealth/.

8. Epstein DA, Lee NB, Kang JH, et al. Examining menstrual tracking to inform the design of personal informatics tools. Proc SIGCHI Conf Hum Factor Comput Syst. 2017;2017:68766888. doi:10.1145/3025453.3025635.

9. Moglia $M$, Nguyen $H$, Chyjek $K$, et al. Evaluation of smartphone menstrual cycle tracking applications using an adapted APPLICATIONS scoring system. Obstet Gynecol. 2016;127:1153-1160. doi:10.1097/AOG.0000000000001444.

10. Chen KT. Top free menstrual cycle tracking apps for your patients. OBG Manag. 2017;27:44-45.

11. Lunde B, Perry R, Sridhar A, et al. An evaluation of contraception education and health promotion applications for patients. Womens Health Issues. 2017;27:29-35. doi:10.1016/j.whi.2016.09.012.

12. Chyjek K, Farag S, Chen KT. Rating pregnancy wheel applications using the APPLICATIONS scoring system. Obstet Gynecol. 2015;125:1478-1483. doi:10.1097 /AOG.0000000000000842.

13. Santo K, Richtering SS, Chalmers J, et al. Mobile phone apps to improve medication adherence: a systematic stepwise process to identify high-quality apps. JMIR Mhealth Uhealth. 2016;4:E132. doi:10.2196/mhealth.6742.

14. Stoyanov SR, Hides L, Kavanagh DJ, et al. Mobile app rating scale: a new tool for assessing the quality of health mobile apps. JMIR Mhealth Uhealth. 2015;3:E27. doi:10.2196 /mhealth.3422. 